\title{
Characterization of the Wine Grape Thermohydrological Conditions in the Tropical Brazilian Growing Region: Long-Term and Future Assessments
}

\author{
Antônio Heriberto de Castro Teixeira, ${ }^{1}$ Jorge Tonietto, ${ }^{2}$ \\ Giuliano Elias Pereira, ${ }^{2}$ and Fernando Braz Tangerino Hernandez ${ }^{3}$ \\ ${ }^{1}$ Embrapa, 13070-115 Campinas, SP, Brazil \\ ${ }^{2}$ Embrapa, 95700-000 Bento Gonçalves, RS, Brazil \\ ${ }^{3}$ São Paulo State University, 15385-000 Ilha Solteira, SP, Brazil \\ Correspondence should be addressed to Jorge Tonietto; heriberto.teixeira@embrapa.br
}

Received 12 November 2013; Accepted 22 December 2013; Published 10 February 2014

Academic Editors: J. Hatfield, N. Hulugalle, and L. Mateos

Copyright (C) 2014 Antônio Heriberto de Castro Teixeira et al. This is an open access article distributed under the Creative Commons Attribution License, which permits unrestricted use, distribution, and reproduction in any medium, provided the original work is properly cited.

\begin{abstract}
Over the last years, Brazil has appeared among the new tropical wine producing countries. The joined effect of rising air temperature and decreasing precipitation makes it important to quantify the trend of the thermohydrological conditions of the commercial vineyards. The aims of the current research were to classify and delimit these conditions for the winemaking processes under different time scenarios in the Brazilian Northeastern region. Bioclimatic indicators were used together with long-term weather data and projections of the IPCC emission scenarios under simulated pruning dates. The results showed that decreasing of precipitation should be good for wine production when irrigation water is available, but rising air temperature will affect the wine quality and stability mainly for pruning done from November to March. The best pruning periods are around May for any time scenario considered. In general, more care should be taken for pruning happening in other periods of the year, regarding the effect of increasing thermal conditions on wine quality. The classification and delimitation done, joined with other ecological characteristics, are important for a rational planning of the commercial wine production expansion, mainly in situations of climate and land use changes together with rising water competition.
\end{abstract}

\section{Introduction}

Long-term observations and models are showing pieces of evidence of alterations in the climate system happening in several places of the world, which can be attributed to human activities. These effects are mainly consequences of changes in the atmospheric composition and hence global average air temperature is projected to rise together with regional variations in precipitation patterns $[1,2]$.

Grapevine phenology, wine quality, and yield are very dependent on climate at regional, local, and microclimatic scales [3]. Regional climate has been the focus of climate change impact assessments. At the local level, the considerations of grape site selection, cultural practices, and water management are increasing, being very important issues for potential adaptations to climate changes [4].
Air temperature values lower than $10^{\circ} \mathrm{C}$ will limit the vine shoot growth, inducing the plants to a dormancy period in temperate climates [5]. The optimum thermal range is considered between 25 and $30^{\circ} \mathrm{C}$ [6]. According to Huglin and Schneider [7], under situations of air temperature higher than $25^{\circ} \mathrm{C}$, net photosynthesis decreases. Above $30^{\circ} \mathrm{C}$, berry size and weight are reduced, with the metabolic processes dropping near $45^{\circ} \mathrm{C}$ [8]. Rising air temperature contributes to high sugar concentration in grapes, resulting in larger alcohol content in wines and lower acidity, increasing $\mathrm{pH}$. As consequences, the presence, intensity and quality of the aroma, colour, and wine stability may be affected negatively $[9,10]$.

Webb et al. [11] analysing air temperature ranges concluded that, by 2030 in Australia, there may be additional areas for growing some grape varieties, but, overall, reductions in 
suitable areas are predicted by 2050 (between 27\%, midwarming, and 44\%, high warming). However, in the USA, White et al. [12] showed that predictions based on average air temperature ranges alone might underestimate the climate changes impacts on viticulture.

According to Ganichot [13], the potential alcohol levels of grapes increased by $2 \%$ (from 9.7 to $22.7 \mathrm{v} / \mathrm{v} \%$ ), while total acidity decreased from 6 to $4 \mathrm{~g} \mathrm{~L}^{-1} \mathrm{H}_{2} \mathrm{SO}_{4}$ and $\mathrm{pH}$ increased from 3.0 to 3.3, across all grape cultivars between 1980 and 2001 in southern France. Jones [14] reviewed reports on increased alcohol levels in wines from Alsace, Australia, and Napa founding that $50 \%$ of their increases are attributed to climate changes.

Besides the direct effects of rising air temperature on vine physiology and grape composition, there are important secondary ones. Increased soil and water salinity is a phenomenon associated with several semiarid and arid regions relying on irrigation $[15,16]$. These joint effects can promote high concentrations of $\mathrm{Na}, \mathrm{K}$, and $\mathrm{Cl}$ in wines [17]. Rising air temperatures $\left(30^{\circ} \mathrm{C}\right)$ may increase suspended solid concentrations, but Brix levels larger than $24^{\circ} \mathrm{C}$ Brix are likely not due to photosynthesis and sugar transport from leaves and woods. These high levels can be attributed to an increase of evapotranspiration (ET), as the warm air close to the canopies is one of the energy sources for the water fluxes [18].

Warming conditions can directly affect the vineyard water requirements, which, together with precipitation reductions, will lead to high levels of both aridity and irrigation water demand [19]. According to Webb et al. [20], the air temperature rise during the harvest period may reduce berry quality through higher ET rates. A prediction of increasing vineyard water consumption up $30 \%$ by 2070 , despite the changes in precipitation patterns, was observed in Australia [21].

Jackson and Cherry [22] reported that high rainfall amounts reduce the ripening capacity of grapes. On the other hand, a certain level of water stress during this stage is favourable for the organoleptic wine quality [7]. Dry weather makes irrigation technologies an important asset for controlling water deficiencies and excesses and the need of vineyard water requirements quantification $[19,21]$.

According to Webb [23] the vineyard-growing season precipitation amounts are predicted to decrease or increase in Australia, depending upon the region, while the aridity is expected to rise in all areas by 2030 and 2050. Generally, these predictions translate the need of a reduction in irrigation water supply through increasing water productivity, which may be considered as the ratio of the actual yield to the water consumption [24].

A range of emission scenarios have been developed in the Intergovernmental Panel on Climate Change (IPCC) Special Reports on Emission Scenarios that reflect ways in which the world might develop [25].

A large number of climate models have classified winemaking regions by using different methodologies (e.g., Bonnardot et al. [26]; Tonietto and Carbonneau [27]). For thermohydrological vineyard delimitation, aiming at grape and wine production, one can apply bioclimatic indices based on the thermohydrological requirements. The Multicriteria
Climatic Classification (MCC) System proposed by Tonietto and Carbonneau [27] has been used under temperate climate conditions in Europe [28, 29] and in South America [30, 31]. However, the method has worked well considering a single, six-month growing season per year under these conditions.

Over the last years, the Brazilian tropical region has appeared among the new wine producing areas. With proper irrigation and cultural management practices, the farmers can produce grapes and carry out winemaking at any time of the year, allowing a potential average of between two to three vineyard-growing cycles per year, in accordance with and depending on each variety [19]. The rise of the air temperature with a consequent increase in aridity in the Brazilian Northeast region will affect the wine quality and water requirements. The joined effect of rising water consumption and decreasing precipitation, together with rapid land use change, makes it important to quantify the vineyard thermohydrological trends on a large scale to subsidize winemaking adaptations and water productivity improvements in the near future.

The objective of this research was to combine bioclimatic indicators, together with long-term weather data and projections of the IPCC A2 and B2 emission scenarios for the years 2020, 2050, and 2080, to classify and delimit the thermohydrological conditions for the winemaking processes under different pruning dates and time scenarios in the Brazilian Northeastern region. The modelling aims to subsidize the rational expansion of wine grape crop and improvements on water productivity, while minimizing undesired climate change effects on wine quality and environmental damages. This information is very important in situations of rising water competition by irrigated agriculture, natural vegetation, and nonagricultural sectors in the present and future conditions.

\section{Materials and Methods}

Figure 1 shows details of the Brazilian geographic regions, with states of the Northeast region and the location of the rain gauges and the conventional agrometeorological stations used.

The available monthly total precipitation data were from SUDENE (Superintendence of Development of the Northeast) referred to 1455 locations of rain gauges, while the monthly mean air temperature data were from INMET (National Meteorological Institute) recorded in 75 conventional stations.

These weather data are long-term values for the period from 1961 to 1990, taken as the baseline conditions in this study and used for comparisons with the IPCC A2 and B2 emission scenarios for the projected years 2020, 2050, and 2080. In the stations with only precipitation data available, the monthly air temperature $\left(T_{\text {month }}\right)$ values were estimated from the geographic coordinates [32].

As the air temperature data is easier to be obtained for the whole Brazilian Northeast than the other meteorological parameters involved in the water vapour transfer, the Thornthwaite (TH) method, which needs only the monthly averages $\left(T_{\text {month }}\right)$ as an input, was first applied to retrieve the monthly reference evapotranspiration (ETo). Available or 


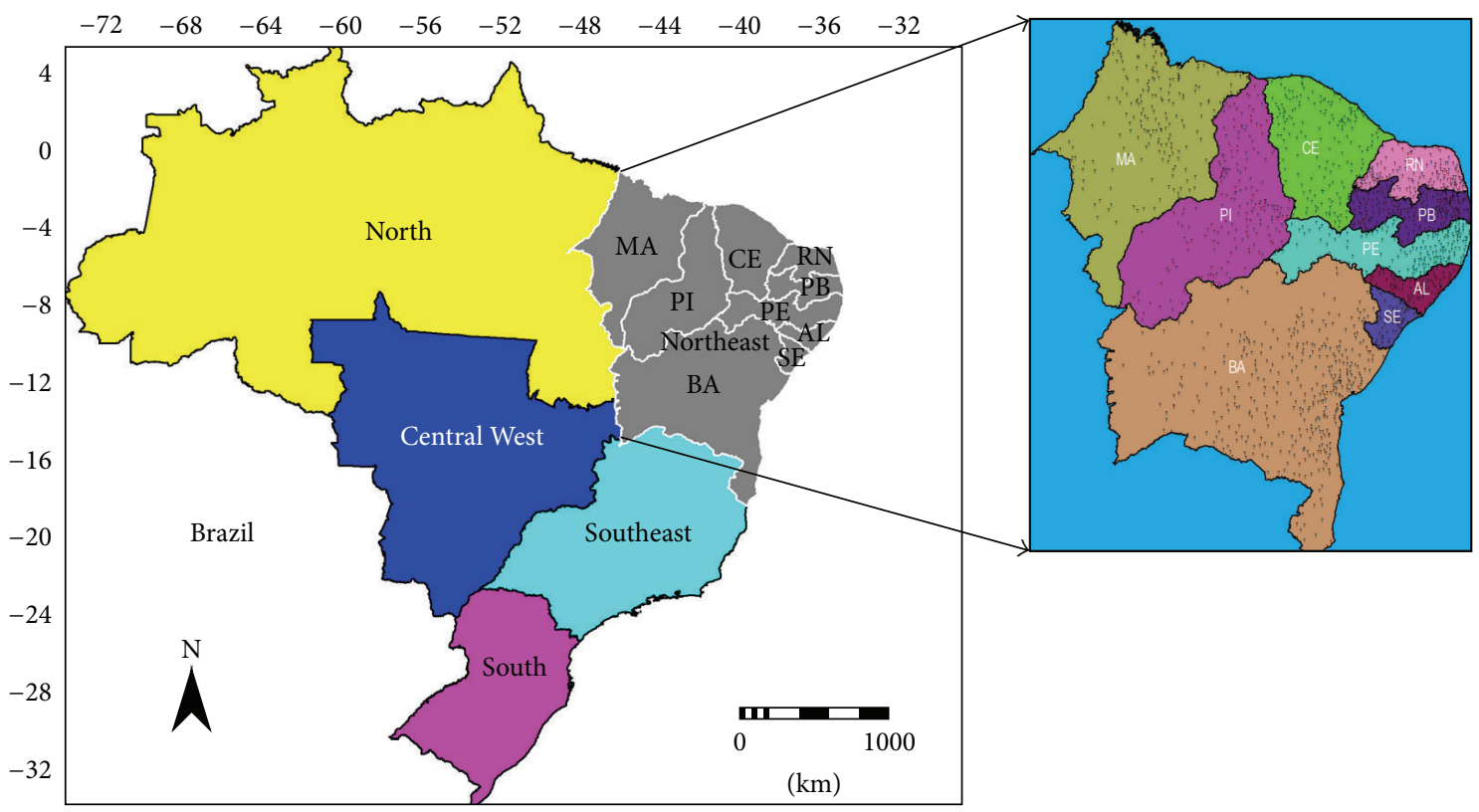

Figure 1: Brazilian regions and the Northeastern states of Maranhão (MA), Piauí (PI), Ceará (CE), Rio Grande do Norte (RN), Paraíba (PB), Pernambuco (PE), Alagoas (AL), Sergipe (SE), and Bahia (BA), together with the locations of the rain gauges and conventional agrometeorological stations.

estimated weather data from the conventional stations were used together with astronomical relations [33].

Simultaneous measurements of potential evapotranspiration (ETp) in wine grape cv. Syrah under optimal soil moisture conditions, together with ETo by the Penman-Monteith (PM) method [34], allowed the acquirement of crop coefficient $\left(K_{c}\right)$ along a complete growing season [35]. Daily data of solar radiation, air temperature and relative humidity, and wind speed from an automatic agrometeorological station were used for the calculation of ETo.

In the current research, a model based on the relation of $K_{c}$ and the accumulated degree days $\left(\mathrm{DD}_{\mathrm{ac}}\right)$ was used to retrieve ETp, considering the cv. Syrah as a reference [19], after applying regression equations for calibrating $\mathrm{ETo}_{\mathrm{TH}}$ into $\mathrm{ETo}_{\mathrm{PM}}$ throughout regression equations. Seven automatic agrometeorological stations in the semiarid conditions of the Brazilian Northeast were used for this calibration:

$$
K_{c}=a \mathrm{GD}_{\mathrm{ac}}^{2}+b \mathrm{GD}_{\mathrm{ac}}+c,
$$

where $a=-2 \times 10^{-7}, b=4 \times 10^{-4}$, and $c=0.54$ are the regression coefficients valid for the Brazilian semiarid conditions, with $R^{2}=0.80$.

For the calibration of $\mathrm{ET}_{\mathrm{TH}}$ into $\mathrm{ET} 0_{\mathrm{PM}}$, before using the model relating $K_{c}$ and $\mathrm{DD}_{\mathrm{ac}}$, the regression equations for the first and for the second semesters were applied separately, both presenting $R^{2}$ around 0.70 . Since the intention is to apply bioclimatic indicators for classifying wine grape areas and not to have accurate ET measurements, this calibration process seems to be plausible considering the absence of all meteorological parameters necessary for PM equation in the whole Brazilian Northeast region.

The ETp for one growing season (GS) was considered as the vineyard water requirements for an average GS of four months $\left(\mathrm{VWR}_{\mathrm{GS}}\right)$. Taking five $K_{c}$ modelled values from $\mathrm{DD}_{\mathrm{ac}}$, and a base air temperature $\left(T_{b}\right)$ of $10^{\circ} \mathrm{C}$, zero being the initial value for $\mathrm{DD}_{\mathrm{ac}}$ and considering the accumulated ones for the first, second, third, and fourth months, the average crop coefficient $\left(K_{c_{\mathrm{GS}}}\right)$ was multiplied by $\mathrm{ETo}_{\mathrm{GS}}$ to give $\mathrm{VWR}_{\mathrm{GS}}$ :

$$
\mathrm{VWR}_{\mathrm{GS}}=K_{c_{\mathrm{GS}}} \mathrm{ETo}_{\mathrm{GS}} .
$$

$\mathrm{VWR}_{\mathrm{GS}}$ together with the mean total precipitation for a growing season $\left(P_{\mathrm{GS}}\right)$ allowed the development and application of a vineyard water indicator $\left(\mathrm{VWI}_{\mathrm{GS}}\right)$ for the moisture delimitations in the Brazilian Northeast, varying the pruning dates:

$$
\mathrm{VWI}_{\mathrm{GS}}=\frac{P_{\mathrm{GS}}}{\mathrm{VWR}_{\mathrm{GS}}} .
$$

The indicator represented by (3) enables the characterization of the water component of the climate, taking into account the input and output of water from and to the vineyards, indicating the potential moisture availability in their root zones.

$\mathrm{VWI}_{\mathrm{GS}}$ values around 1.00 imply the feasibility for rainfed wine grape crop, while those much higher indicate unsuitable conditions independently of irrigation water availability, due to problems of moisture excess. Low $\mathrm{VWI}_{\mathrm{GS}}$ values mean natural water deficiencies and the degree of irrigation needs according to the pruning dates.

The future scenarios were considered by using precipitation and air temperature data for the projected years cantered on 2020, 2050, and 2080 from IPCC reports [1,2] simulated by the model HadCM3 from the Hadley centre [36], which was chosen because it was the one that best agreed with 
observed historical weather data among others tested in South America [37].

The baseline and projected weather data were interpolated in a Geographic Information System (GIS) environment, by the "moving average" method, and the thermohydrological models were applied to the grids of $P_{\mathrm{GS}}$ and $T_{\mathrm{GS}}$.

Basic criteria for dividing the Northeastern region into four classes (C1, C2, C3, and C4) of vineyard thermohydrological conditions were used. First, the $\mathrm{VWI}_{\mathrm{GS}}$ values were considered the most important factor, as the excessive moisture is not suitable for the wine grape crop, independently if irrigated or not.

When $\mathrm{VWI}_{\mathrm{GS}}$ values are lower or equal to 2.00 (classes $\mathrm{C} 1$ and $\mathrm{C} 2$ ), the moisture conditions are the best, because of less plant diseases, root respiration problems, and direct damage to the fruits promoted by excess of precipitation. These conditions will favour better quality of must and wine, where, according to data from the Brazilian Geographical and Statistical Institute (IBGE), the commercial wine grapes are concentrated in the Brazilian Northeastern region.

As warmer conditions affect negatively the wine quality, the most suitable areas in relation to moisture conditions were classified according to a $T_{\mathrm{GS}}$ threshold of $24^{\circ} \mathrm{C}$. $\mathrm{Cl}$ areas were considered those with $T_{\mathrm{GS}}$ below $24^{\circ} \mathrm{C}$ and $\mathrm{C} 2$ areas are those above this value. Although the latter class has suitable natural moisture conditions for irrigated wine crop, as long as the air temperature increases above this threshold value, the wine quality should be affected, contributing to high levels of alcohol, low acidity, and large $\mathrm{pH}$ values, becoming unbalanced with instability for the phenolic and aromatic composition.

In situations of $\mathrm{VWI}_{\mathrm{GS}}$ being higher than 2.00, the growing wine grape areas and yield are reduced, according to data from IBGE. A class with $\mathrm{VWI}_{\mathrm{GS}}$ higher than 2.00 and lower or equal to 4.00 was then considered as an intermediary one; insofar the natural moisture increases, the yield and wine quality should be affected, independently of the thermal conditions.

Areas and pruning dates inside the worst class, those having $\mathrm{VWI}_{\mathrm{GS}}$ higher than 4.00 , should present the biggest problems in grape yield due to high levels of natural humidity that compromise the grape sanity, enological potential, and consequently the wine quality. There is no commercial wine grape crop reported by the IBGE under these conditions in the Brazilian Northeastern states.

\section{Results}

3.1. Long-Term Vineyard Thermohydrological Conditions. Figure 2 shows the maps of the $T_{\mathrm{GS}}$ long-term values, for, respectively, the coldest and the hottest GS, with pruning dates in July and October (Figure 2(a)), respectively, and those of $P_{\mathrm{GS}}$, for the wettest and the driest conditions, with pruning dates in January and June (Figure 2(b)), respectively.

The lowest $T_{\mathrm{GS}}$ values occur at the winter solstice time in the Southern hemisphere, while the highest ones are found when the Sun is around the zenith position over the central part of the Brazilian Northeastern region. For pruning in July, many pixels present $T_{\mathrm{GS}}$ values lower than $22.0^{\circ} \mathrm{C}$, while one can see a larger area with those higher than $24.0^{\circ} \mathrm{C}$, for pruning in October (Figure 2(a)).

Analysing the $P_{\mathrm{GS}}$ maps (Figure 2(b)), during the wettest GS, Maranhão (MA) and the Northwestern side of Piauí (PI) state are the most problematic areas, because of the Amazon's climatic influences, with total averaged values higher than $750 \mathrm{~mm}$. When the pruning occurs during the driest period, almost the whole Northeast Brazil shows $P_{\mathrm{GS}}$ long-term values below $400 \mathrm{~mm}$, even lower than $150 \mathrm{~mm}$ in the central and Southwestern areas of the region.

Figure 3 shows the spatial variation of the $\mathrm{VWR}_{\mathrm{GS}}$ values for the reference cv. Syrah, under different pruning dates and an average GS of four months, based on the long-term data from 1961 to 1990 (baseline conditions), in the Brazilian Northeast region.

The pruning dates with maximum $\mathrm{VWR}_{\mathrm{GS}}$ values are in September, when the average is $410 \mathrm{~mm} \mathrm{GS}^{-1}$, while the lowest ones are found when they are in March, around $300 \mathrm{~mm} \mathrm{GS}^{-1}$. According to the standard deviations (SD), the smallest and the largest spatial variations occur, respectively, for pruning done from March to May $\left(\mathrm{SD}=18 \mathrm{~mm} \mathrm{GS}^{-1}\right)$ and between August and October $\left(\mathrm{SD}=23 \mathrm{~mm} \mathrm{GS}^{-1}\right)$.

Table 1 presents the variation of $\mathrm{VWR}_{\mathrm{GS}}$ for the reference cv. Syrah, among the Brazilian Northeastern states, considering the baseline conditions (1961-1990) and different pruning dates for a four-month average GS.

Highlights are for Piauí (PI), Ceará (CE), and Rio Grande do Norte (RN) as the states with the largest vineyard water demands. The highest average values are found in Ceará (CE), while the lowest ones are for Bahia (BA) state. The extremes of $\mathrm{VWR}_{\mathrm{GS}}$ values represent a daily range from 2.5 to $3.3 \mathrm{~mm} \mathrm{~d}^{-1}$.

For the delimitation of the thermohydrological conditions of the reference wine grape cv. Syrah, considering different pruning dates and an average four months GS, the bioclimatic indicator $\mathrm{VWI}_{\mathrm{GS}}$ was first considered for the baseline conditions (Figure 4).

Pruning dates between June and August present the largest area of natural climate dryness conditions. Under these circumstances the $\mathrm{VWI}_{\mathrm{GS}}$ values are below 0.50 and the $\mathrm{SD}$ between 0.25 and 0.40 . On the other hand, $\mathrm{VWI}_{\mathrm{GS}}$ larger than 2.00 and $\mathrm{SD}$ above 0.70 occur in larger areas for pruning dates from December to April, mainly in the Northwestern side of Maranhão (MA) state.

Table 2 presents the average $\mathrm{VWI}_{\mathrm{GS}}$ values per state, for the wine grape cv. Syrah, considering different pruning dates along the year and an average growing season of four months, in the Brazilian Northeast, by using weather data for the baseline conditions (1961-1990).

$\mathrm{VWI}_{\mathrm{GS}}$ values around 2.00 or higher for the rainy period are found in Maranhão (MA), Piauí (PI), and Ceará (CE) states. The lowest ones occur during the driest pruning periods, in Ceará (CE) and Rio Grande do Norte (RN), with averages even bellow 0.10 .

Figure 5 shows the delimitation of four classes, according to the thermohydrological conditions for the baseline conditions, considering different pruning dates along the year, the reference wine grape crop cv. Syrah, and an average GS of four months. 


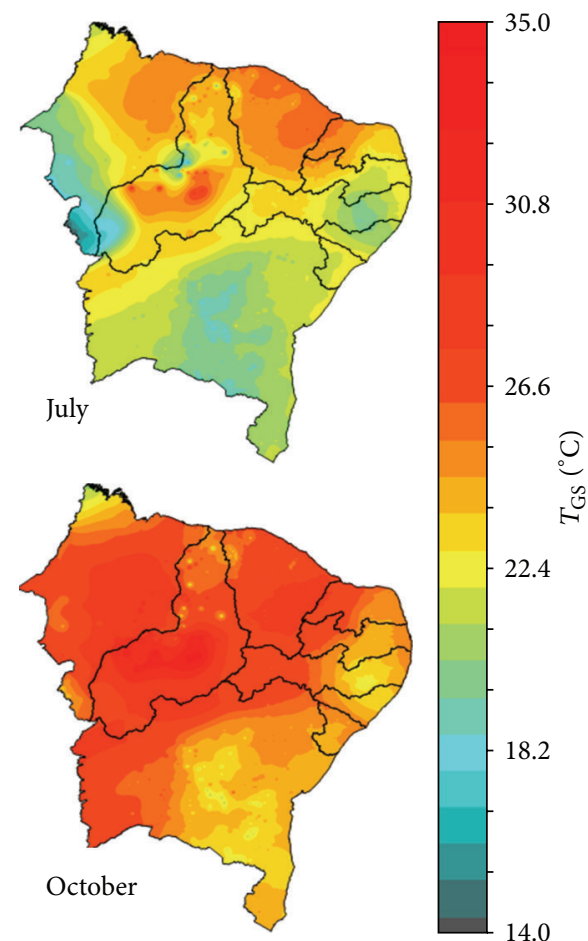

(a)

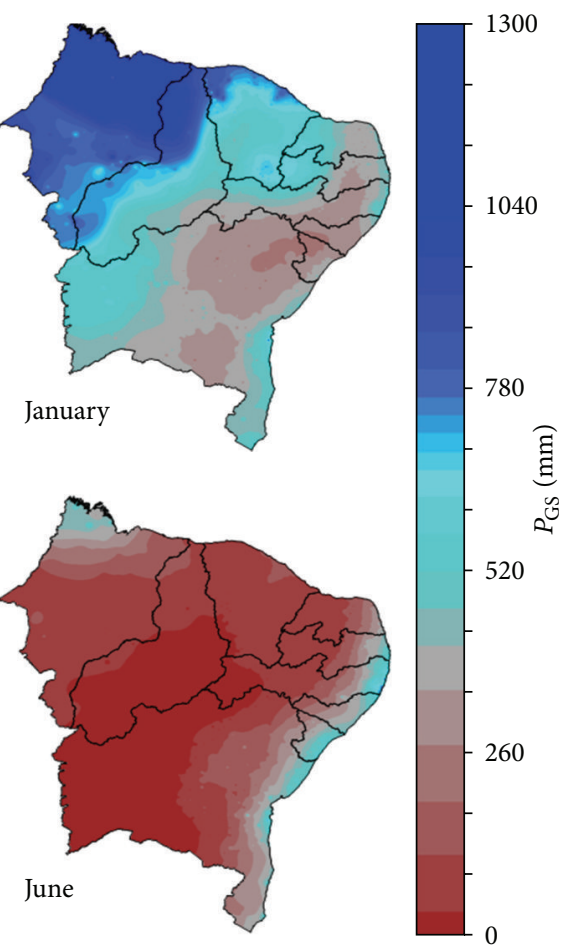

(b)

FIGURE 2: Maps of the long-term weather values (1961-1990) for an average wine grape growing season of four months in the Brazilian Northeastern region: (a) mean air temperature for the coldest and the hottest conditions $\left(T_{\mathrm{GS}}\right)$, with pruning dates, respectively, in July and October and (b) total precipitation, for the wettest and the driest conditions $\left(P_{\mathrm{GS}}\right)$, with pruning dates, respectively, in January and June.

TABLE 1: Mean values of the vineyard grape water requirements, cv. Syrah, for different pruning dates, considering an average growing season of four months $\left(\mathrm{VWR}_{\mathrm{GS}}\right)$ and the baseline conditions (1961-1990) in the Brazilian Northeastern states of Maranhão (MA), Piauí (PI), Ceará (CE), Rio Grande do Norte (RN), Paraíba (PB), Pernambuco (PE), Alagoas (AL), Sergipe (SE), and Bahia (BA).

\begin{tabular}{|c|c|c|c|c|c|c|c|c|c|}
\hline Pruning date & $\begin{array}{c}\mathrm{VWR}_{\text {GS_MA }} \\
(\mathrm{mm})\end{array}$ & $\begin{array}{c}\mathrm{VWR}_{\mathrm{GS} \_\mathrm{PI}} \\
(\mathrm{mm})\end{array}$ & $\begin{array}{c}\mathrm{VWR}_{\mathrm{GS} \_\mathrm{CE}} \\
(\mathrm{mm})\end{array}$ & $\begin{array}{c}\mathrm{VWR}_{\mathrm{GS}_{\text {RN }}} \\
(\mathrm{mm})\end{array}$ & $\begin{array}{c}\mathrm{VWR}_{\text {GS_PB }} \\
(\mathrm{mm})\end{array}$ & $\begin{array}{c}\mathrm{VWR}_{\mathrm{GS}_{2} \mathrm{PE}} \\
(\mathrm{mm})\end{array}$ & $\begin{array}{c}\begin{array}{c}\mathrm{VWR}_{\mathrm{GS} A A L} \\
(\mathrm{~mm})\end{array} \\
\end{array}$ & $\begin{array}{c}\begin{array}{c}\text { VWR } \\
(\mathrm{mm} / S E\end{array} \\
(\mathrm{mm})\end{array}$ & $\begin{array}{c}\mathrm{VWR}_{\mathrm{GS}_{2} \mathrm{BA}} \\
(\mathrm{mm})\end{array}$ \\
\hline January & 278.6 & 312.9 & 327.0 & 336.2 & 319.2 & 319.2 & 318.3 & 331.4 & 311.2 \\
\hline February & 271.2 & 304.0 & 313.2 & 323.8 & 306.1 & 304.9 & 306.7 & 321.5 & 301.4 \\
\hline March & 269.5 & 298.0 & 309.0 & 316.0 & 297.6 & 294.3 & 295.2 & 308.3 & 288.6 \\
\hline April & 287.7 & 308.8 & 324.9 & 325.1 & 307.8 & 302.0 & 300.9 & 311.5 & 295.0 \\
\hline May & 319.0 & 329.0 & 348.2 & 341.4 & 324.3 & 316.6 & 312.3 & 320.4 & 312.0 \\
\hline June & 352.5 & 358.3 & 375.0 & 363.1 & 348.0 & 341.0 & 332.5 & 336.4 & 336.5 \\
\hline July & 392.8 & 401.8 & 405.2 & 390.9 & 378.7 & 374.6 & 363.0 & 366.0 & 374.8 \\
\hline August & 406.5 & 420.5 & 415.0 & 400.1 & 389.4 & 388.4 & 374.3 & 376.5 & 385.9 \\
\hline September & 408.7 & 428.9 & 422.5 & 409.1 & 389.4 & 400.4 & 386.6 & 389.1 & 399.8 \\
\hline October & 382.6 & 408.5 & 409.5 & 399.8 & 389.1 & 390.3 & 378.0 & 383.1 & 376.6 \\
\hline November & 344.0 & 371.0 & 383.5 & 379.8 & 367.0 & 367.2 & 359.0 & 366.7 & 351.1 \\
\hline December & 312.2 & 341.5 & 357.8 & 361.4 & 346.1 & 345.8 & 341.9 & 353.0 & 333.7 \\
\hline Year & 335.4 & 356.9 & 365.9 & 362.2 & 346.9 & 345.4 & 339.1 & 347.0 & 338.9 \\
\hline
\end{tabular}

The largest sizes for the $\mathrm{C} 1$ and $\mathrm{C} 2$ classes occur, respectively, when the pruning dates are from April to June $(62 \%$ of the region) and from September to November (78\% of the region). The classes $\mathrm{C} 3$ and $\mathrm{C} 4$ occur mostly when the pruning is done from December to February (28\% of the region) and from January to March (5\% of the region), respectively. The highest concentration is for $\mathrm{C} 2$ class when the pruning dates are in October, representing more than $80 \%$ of the Brazilian Northeast, while pruning periods in May present more than $65 \%$ of areas classified as $\mathrm{Cl}$. 

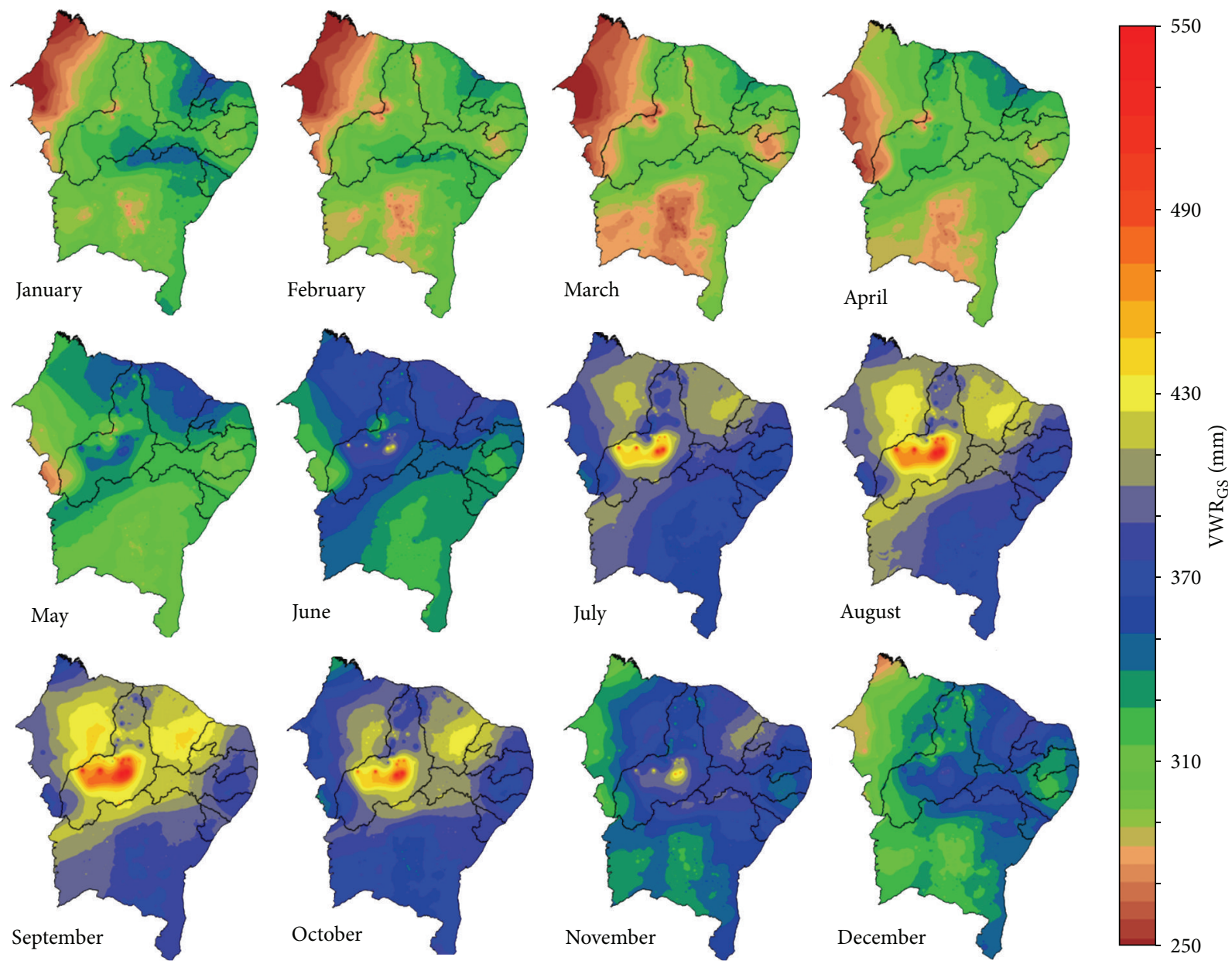

250

FIGURE 3: Maps of the wine grape water requirements, cv. Syrah, for different pruning dates, an average growing season of four months $\left(\mathrm{VWR}_{\mathrm{GS}}\right.$ ), and the baseline conditions (1961-1990), in the Brazilian Northeastern region.

TABLE 2: Mean values of the vineyard water index for the wine grape, cv. Syrah, considering an average growing season (VWI $\mathrm{GS}_{\mathrm{GS}}$ ) of four months and the baseline conditions (1961-1990), in the Brazilian Northeastern states of Maranhão (MA), Piauí (PI), Ceará (CE), Rio Grande do Norte (RN), Paraíba (PB), Pernambuco (PE), Alagoas (AL), Sergipe (SE), and Bahia (BA).

\begin{tabular}{|c|c|c|c|c|c|c|c|c|c|}
\hline Pruning date & $\mathrm{VWI}_{\mathrm{GS} \_\mathrm{MA}}$ & $\mathrm{VWI}_{\mathrm{GS} \_\mathrm{PI}}$ & $\mathrm{VWI}_{\mathrm{GS}_{\text {CE }}}$ & $\mathrm{VWI}_{\mathrm{GS} \_\mathrm{RN}}$ & $\mathrm{VWI}_{\mathrm{GS} \_\mathrm{PB}}$ & $\mathrm{VWI}_{\mathrm{GS} \_\mathrm{PE}}$ & $\mathrm{VWI}_{\text {GS_AL }}$ & $\mathrm{VWI}_{\mathrm{GS} \_\mathrm{SE}}$ & $\mathrm{VWI}_{\mathrm{GS} \_\mathrm{BA}}$ \\
\hline January & 3.52 & 2.18 & 1.92 & 1.39 & 1.46 & 1.28 & 0.99 & 0.94 & 1.32 \\
\hline February & 3.36 & 1.89 & 2.07 & 1.59 & 1.61 & 1.35 & 1.30 & 1.35 & 1.11 \\
\hline March & 2.67 & 1.41 & 1.79 & 1.51 & 1.55 & 1.30 & 1.55 & 1.67 & 0.90 \\
\hline April & 2.48 & 1.36 & 1.70 & 1.47 & 1.50 & 1.27 & 1.52 & 1.65 & 0.88 \\
\hline May & 0.77 & 0.24 & 0.49 & 0.64 & 0.75 & 0.69 & 1.37 & 1.62 & 0.41 \\
\hline June & 0.39 & 0.11 & 0.19 & 0.37 & 0.49 & 0.49 & 1.03 & 1.23 & 0.34 \\
\hline July & 0.34 & 0.17 & 0.09 & 0.20 & 0.30 & 0.33 & 0.68 & 0.85 & 0.38 \\
\hline August & 0.45 & 0.36 & 0.07 & 0.10 & 0.18 & 0.23 & 0.42 & 0.58 & 0.59 \\
\hline September & 0.71 & 0.61 & 0.12 & 0.10 & 0.18 & 0.27 & 0.33 & 0.44 & 0.84 \\
\hline October & 1.24 & 1.00 & 0.32 & 0.20 & 0.29 & 0.40 & 0.34 & 0.41 & 1.11 \\
\hline November & 1.93 & 1.44 & 0.69 & 0.45 & 0.55 & 0.63 & 0.46 & 0.49 & 1.32 \\
\hline December & 2.76 & 1.89 & 1.30 & 0.90 & 1.00 & 0.98 & 0.69 & 0.63 & 1.36 \\
\hline Year & 1.72 & 1.06 & 0.90 & 0.74 & 0.84 & 0.77 & 0.89 & 0.99 & 0.88 \\
\hline
\end{tabular}



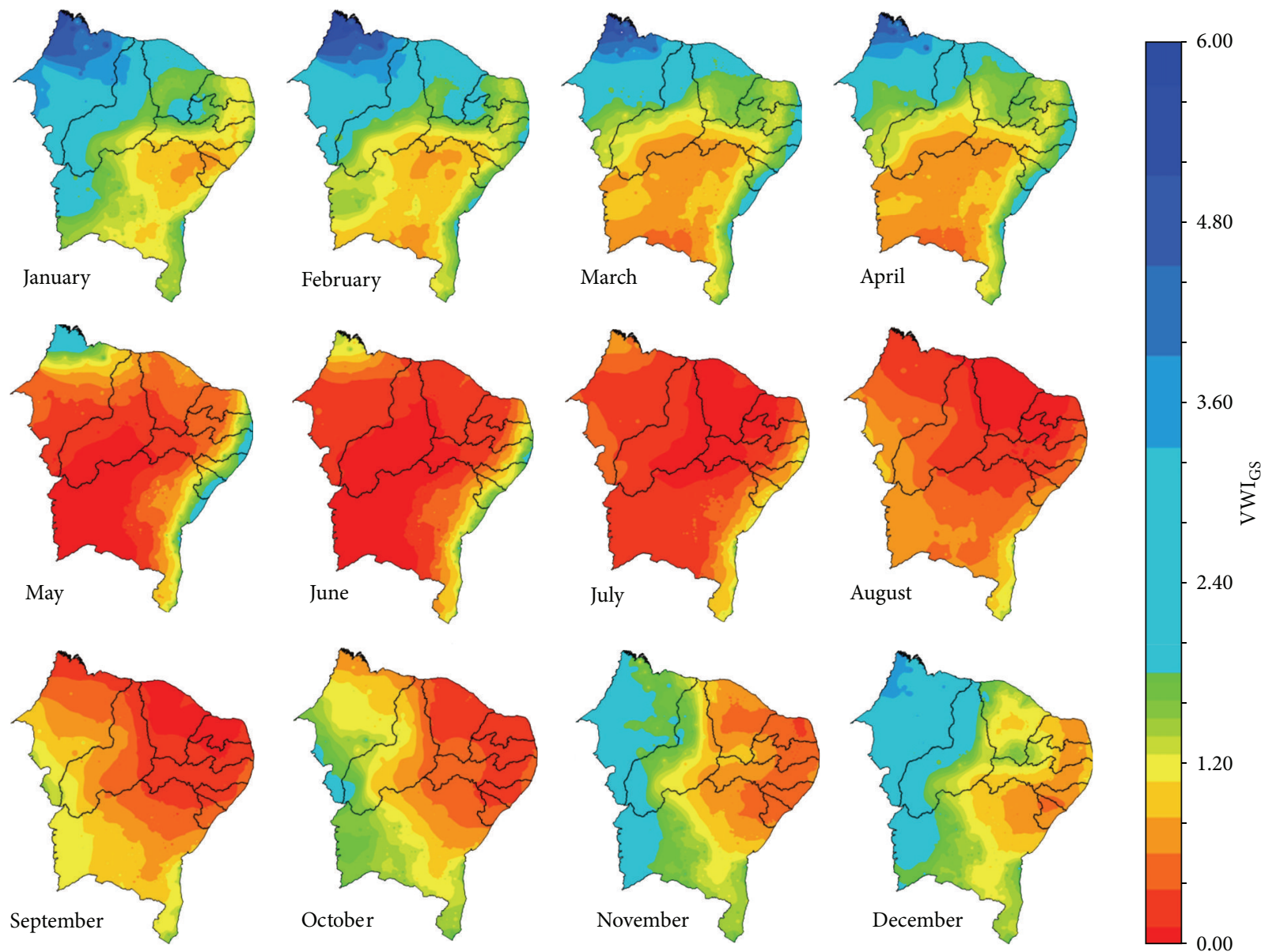

Figure 4: Maps of the vineyard water indicator for the wine grape, cv. Syrah, for different pruning dates, an average growing season of four months $\left(\mathrm{VWI}_{\mathrm{GS}}\right.$ ), and the baseline conditions (1961-1990), in the Brazilian Northeastern region.

\subsection{Projected Vineyard Thermohydrological Conditions.} Table 3 presents the averaged values of the differences $(\Delta)$ for the wine grape thermohydrological indicators, between the baseline conditions (1961-1990) and the projected years (2020, 2050, and 2080), considering the IPCC A2 and B2 emission scenarios for the entire Brazilian Northeastern region.

A generalized $T_{\mathrm{GS}}$ increase is evident for any pruning date; however, the lowest $\Delta T_{\mathrm{GS}}$ values are predicted with pruning occurring from June to August. On the other hand, the highest ones are from November to March, being even larger than $5.0^{\circ} \mathrm{C} \mathrm{GS}^{-1}$, considering the projected year of 2080 and the IPCC A2 emission scenario. These $T_{\mathrm{GS}}$ increases will make the vineyard water consumption rise, as evidenced by the predicted $\Delta \mathrm{VWR}_{\mathrm{GS}}$ averages, higher than $180 \mathrm{~mm} \mathrm{GS}^{-1}$ for pruning dates in December.

In parallel to the $T_{\mathrm{GS}}$ increases, decreases in $P_{\mathrm{GS}}$ values, according to the pruning dates, are also generally evident. The most negative $\Delta \mathrm{VWR}_{\mathrm{GS}}$ values are during the rainy period, when the $P_{\mathrm{GS}}$ values are expected to have an average reduction of more than $250 \mathrm{~mm} \mathrm{GS}^{-1}$ by the year 2080, for pruning dates between February and March.

The simultaneous increases in $\mathrm{VWR}_{\mathrm{GS}}$ and reductions in $P_{\mathrm{GS}}$ will cause a progressive negative trend in $\mathrm{VWI}_{\mathrm{GS}}$. The average annual values are expected to have a reduction of more than -0.60 by the projected year of 2080 from both IPCC scenarios. The exceptions are for pruning dates from November to December for the projected year of 2020 and the IPCC A2 emission scenario, when the values remain stable, as a consequence of the expected increases in $P_{\mathrm{GS}}$.

The spatial variations of the $P_{\mathrm{GS}}$ differences between the baseline and the projected years $\left(\Delta P_{\mathrm{GS}}\right)$ in percentages, for three different wine grape pruning dates along the year, taking as reference the cv. Syrah, in the Brazilian Northeastern region, are shown in Figure 6. Positive values mean increases, while the negative ones represent decreases.

For both IPCC emission scenarios strong $P_{\mathrm{GS}}$ reductions are predicted in large areas, mainly when the pruning dates are around May. However, in some places, more notable for pruning centred in January in the southern side of Bahia (BA) state, there are signs of rainfall increases, especially for the projected years of 2020 and 2050.

The spatial variations of the $\mathrm{VWR}_{\mathrm{GS}}$ differences between the baseline and the projected years $\left(\Delta \mathrm{VWR}_{\mathrm{GS}}\right)$, for three different wine grape pruning date conditions along the year, taking the cv. Syrah as reference, in the Brazilian Northeastern region, are presented in Figure 7, also in percentages. 

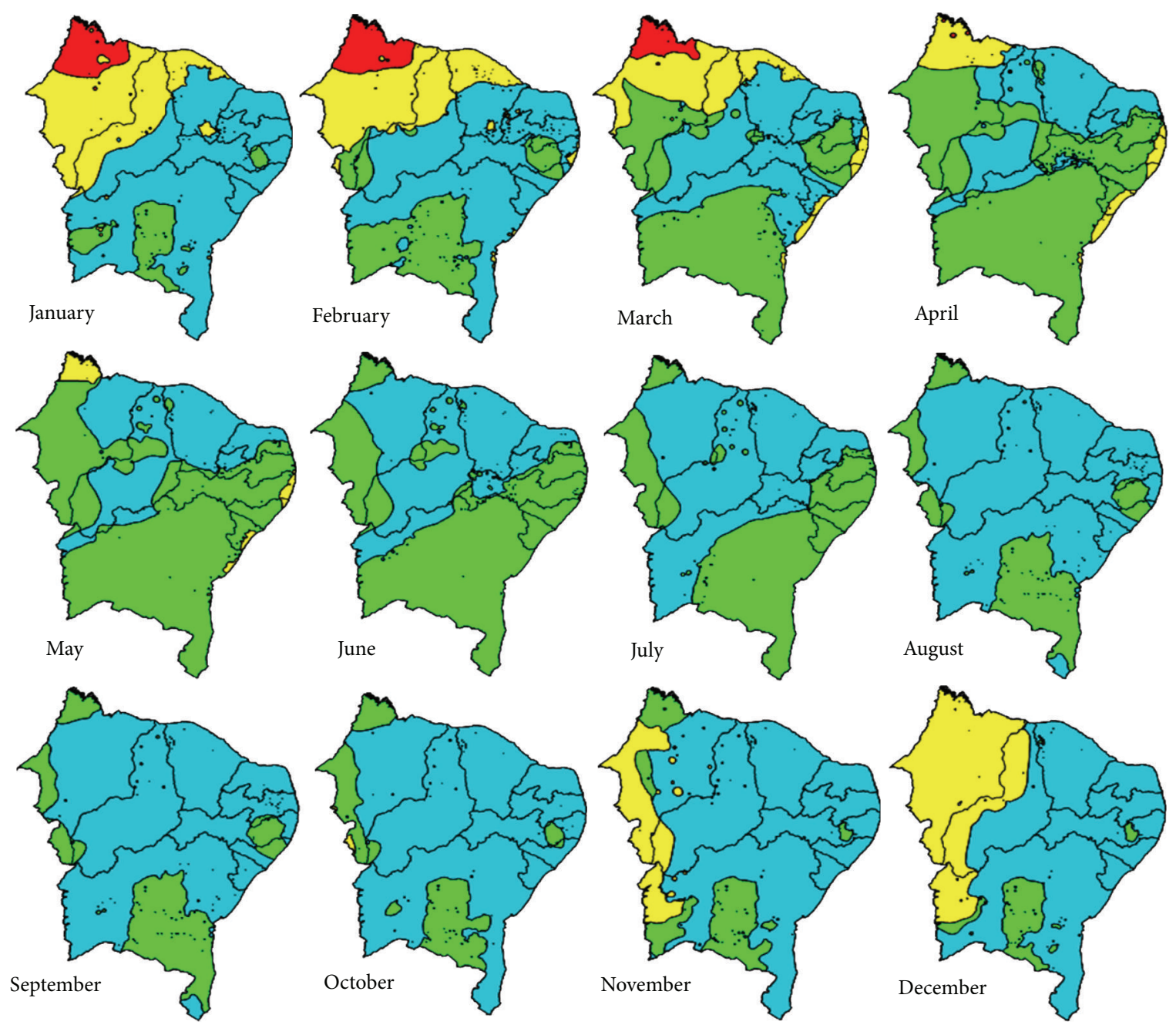

- $\mathrm{C} 1: \mathrm{VWI}_{\mathrm{GS}} \leq 2$ and $T_{\mathrm{GS}}<24^{\circ} \mathrm{C}$

- $\mathrm{C} 2: \mathrm{VWI}_{\mathrm{GS}} \leq 2$ and $T_{\mathrm{GS}} \geq 24^{\circ} \mathrm{C}$

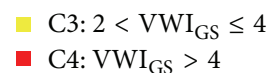

FIGURE 5: Class maps of the thermohydrological conditions for the wine grape, cv. Syrah, under different pruning dates, an average growing season of four months, and the baseline conditions (1961-1990), in the Brazilian Northeastern region.

Although all areas have predictions for rising vineyard water demands, lower $\Delta \mathrm{VWR}_{\mathrm{GS}}$ values are verified for the 2020 projected year, with the minor ranges for pruning around September, mainly in the southern side of Bahia (BA) state. Considering the projected year of 2080 strong increases are predicted, especially during the wettest period represented by the pruning centred in January for IPCC A2 emission scenario, with highlights for Ceará (CE) and Piauí (PI) and the western part of Rio Grande do Norte (RN), Paraíba (PB), and Pernambuco (PE) states.

The spatial variation for the differences between the baseline and the projected years of the vineyard water indicator $\left(\Delta \mathrm{VWI}_{\mathrm{GS}}\right)$, for three different wine grape pruning date conditions along the year, taking as reference the cv. Syrah, in the Brazilian Northeastern region, is shown in Figure 8.

In general, there are decreases in $\mathrm{VWI}_{\mathrm{GS}}$, with the highest ones occurring for pruning dates around January as a result of the predictions of reducing $P_{\mathrm{GS}}$ and increasing $\mathrm{VWR}_{\mathrm{GS}}$. The most negative $\Delta \mathrm{VWI}_{\mathrm{GS}}$ values are in the Northwestern side of Maranhão (MA) state. For the Southwestern side of Bahia (BA) state, more increases in $\mathrm{VWI}_{\mathrm{GS}}$ are predicted.

Analyses were done on how the initial four thermohydrological classes for wine grape could be changed along the IPCC projected years, considering three different pruning date conditions along the year, for the reference cv. Syrah, in the Brazilian Northeastern region (Figure 9).

By the projected year of 2080, almost all the Brazilian Northeastern states are predicted to present larger C2 areas. However, for pruning dates around May, there are still predictions of the $\mathrm{Cl}$ class, mainly in the southern side of Bahia state.

C3 areas will progressively be reduced, being restricted for pruning done around January, while the worst class $\mathrm{C} 4$ arising in the Northwestern part of Maranhão state, for pruning dates 
TABLE 3: Average differences for the wine grape growing season values of air temperature $\left(\Delta T_{\mathrm{GS}}\right)$, precipitation $\left(\Delta P_{\mathrm{GS}}\right)$, vineyard water requirements $\left(\Delta \mathrm{VWR}_{\mathrm{GS}}\right)$, and vineyard water index $\left(\Delta \mathrm{VWI}_{\mathrm{GS}}\right)$ between the baseline conditions (1961-1990) and the projected years of 2020, 2050, and 2080, in the Brazilian Northeastern region, considering the reference cv. Syrah: IPCC A2 (a) and B2 (b) emission scenarios.

(a) A2 emission scenario

\begin{tabular}{lcccccccccccc}
\hline \multirow{2}{*}{ Pruning date } & \multicolumn{3}{c}{$\Delta \mathrm{T}_{\mathrm{GS}}\left({ }^{\circ} \mathrm{C}\right)$} & \multicolumn{3}{c}{$\Delta P_{\mathrm{GS}}(\mathrm{mm})$} & \multicolumn{3}{c}{$\Delta \mathrm{VWR}_{\mathrm{GS}}(\mathrm{mm})$} & \multicolumn{3}{c}{$\Delta \mathrm{VWI} \mathrm{GS}(-)$} \\
& 2020 & 2050 & 2080 & 2020 & 2050 & 2080 & 2020 & 2050 & 2080 & 2020 & 2050 & 2080 \\
\hline January & 1.5 & 3.0 & 5.6 & -7.4 & -88.0 & -217.1 & 31.8 & 68.9 & 170.9 & -0.20 & -0.57 & -1.14 \\
February & 1.6 & 3.1 & 5.5 & -110.4 & -165.9 & -269.3 & 32.3 & 69.3 & 156.7 & -0.51 & -0.79 & -1.22 \\
March & 1.6 & 3.1 & 5.3 & -161.8 & -206.5 & -265.8 & 27.6 & 60.6 & 132.9 & -0.64 & -0.84 & -1.10 \\
April & 1.5 & 3.0 & 5.0 & -177.1 & -198.9 & -233.9 & 25.9 & 53.1 & 108.9 & -1.08 & -1.17 & -1.30 \\
May & 1.4 & 2.8 & 4.6 & -121.9 & -137.1 & -148.6 & 22.7 & 44.6 & 86.1 & -0.39 & -0.44 & -0.48 \\
June & 1.3 & 2.6 & 4.1 & -89.5 & -97.3 & -102.7 & 22.8 & 42.0 & 71.7 & -0.26 & -0.29 & -0.30 \\
July & 1.3 & 2.6 & 4.0 & -84.7 & -89.6 & -94.8 & 19.8 & 40.4 & 72.4 & -0.23 & -0.25 & -0.26 \\
August & 1.3 & 2.7 & 4.2 & -84.9 & -91.7 & -114.0 & 19.7 & 43.1 & 89.5 & -0.22 & -0.23 & -0.31 \\
September & 1.5 & 2.9 & 4.5 & -57.2 & -76.5 & -124.3 & 19.3 & 46.3 & 112.5 & -0.16 & -0.18 & -0.36 \\
October & 1.5 & 2.9 & 5.0 & 13.4 & -38.5 & -118.0 & 19.1 & 48.5 & 119.3 & -0.01 & -0.18 & -0.44 \\
November & 1.5 & 3.0 & 5.4 & 59.9 & -5.6 & -129.3 & 28.6 & 62.4 & 155.8 & 0.07 & -0.28 & -0.62 \\
December & 1.5 & 3.0 & 5.6 & 75.4 & -11.1 & -142.1 & 29.3 & 65.9 & 186.1 & 0.09 & -0.28 & -0.85 \\
\hline Average & 1.5 & 2.9 & 4.9 & -62.2 & -100.6 & -163.3 & 24.9 & 53.8 & 121.9 & -0.30 & -0.46 & -0.70 \\
\hline
\end{tabular}

(b) B2 emission scenario

\begin{tabular}{lcccccccccccc}
\hline \multirow{2}{*}{ Pruning date } & \multicolumn{3}{c}{$\Delta T_{\mathrm{GS}}\left({ }^{\circ} \mathrm{C}\right)$} & \multicolumn{3}{c}{$\Delta P_{\mathrm{GS}}(\mathrm{mm})$} & \multicolumn{3}{c}{$\Delta \mathrm{VWR}_{\mathrm{GS}}(\mathrm{mm})$} & \multicolumn{3}{c}{$\Delta \mathrm{VWI} \mathrm{GS}(-))$} \\
& 2020 & 2050 & 2080 & 2020 & 2050 & 2080 & 2020 & 2050 & 2080 & 2020 & 2050 & 2080 \\
\hline January & 1.3 & 2.6 & 4.0 & -106.1 & -69.8 & -203.9 & 27.8 & 58.2 & 107.9 & -0.47 & -0.48 & -0.99 \\
February & 1.4 & 2.8 & 3.6 & -133.8 & -162.8 & -252.1 & 29.2 & 60.8 & 86.6 & -0.57 & -0.75 & -1.07 \\
March & 1.3 & 2.6 & 3.4 & -172.0 & -207.2 & -267.0 & 23.7 & 50.5 & 68.0 & -0.65 & -0.82 & -1.03 \\
April & 1.2 & 2.5 & 3.4 & -179.4 & -198.9 & -222.8 & 21.8 & 43.0 & 65.3 & -1.08 & -1.16 & -1.25 \\
May & 1.2 & 2.3 & 3.2 & -124.7 & -135.7 & -143.9 & 19.5 & 36.7 & 54.2 & -0.39 & -0.43 & -0.46 \\
June & 1.1 & 2.2 & 2.9 & -91.1 & -97.8 & -99.4 & 20.0 & 35.2 & 49.8 & -0.27 & -0.29 & -0.29 \\
July & 1.3 & 2.1 & 2.8 & -85.1 & -93.4 & -93.3 & 16.5 & 31.9 & 46.9 & -0.23 & -0.25 & -0.25 \\
August & 1.1 & 2.2 & 3.0 & -82.6 & -90.3 & -105.0 & 16.4 & 34.5 & 53.8 & -0.22 & -0.24 & -0.28 \\
September & 1.3 & 2.5 & 3.0 & -56.3 & -72.2 & -110.6 & 16.3 & 37.8 & 50.4 & -0.16 & -0.21 & -0.31 \\
October & 1.2 & 2.5 & 3.6 & -62.2 & -17.1 & -107.0 & 14.9 & 54.2 & 78.2 & -0.19 & -0.11 & -0.37 \\
November & 1.3 & 2.7 & 4.0 & -30.0 & 22.9 & -98.1 & 25.7 & 37.4 & 100.9 & -0.16 & -0.10 & -0.47 \\
December & 1.4 & 2.8 & 3.7 & -25.1 & 11.5 & -130.7 & 26.4 & 57.7 & 93.5 & -0.18 & -0.20 & -0.64 \\
\hline Average & 1.3 & 2.5 & 3.4 & -95.7 & -92.6 & -152.8 & 21.5 & 44.8 & 71.3 & -0.38 & -0.42 & -0.62 \\
\hline
\end{tabular}

during the rainy conditions in January, will practically disappear along the years (see Figures 7 and 9).

\section{Discussion}

According to the long-term data, there are no thermal limitations for wine grape crop in the Brazilian Northeast, with pruning dates in the middle of the year. On one hand, several situations are inside the optimum average range of air temperature from 25 to $30^{\circ} \mathrm{C}$ [6]. On the other hand, the air temperature values are not below the threshold of $10^{\circ} \mathrm{C}[5]$, which could introduce a dormancy stage.

When the pruning is around October, many areas with thermal conditions outside the upper limit (over $30.0^{\circ} \mathrm{C}$ ) often occur and could bring some limitations for wine quality. These latter situations will contribute to high sugar content in grapes but wines with increasing levels of alcohol, low acidity, and large $\mathrm{pH}$ values. These effects together will promote 

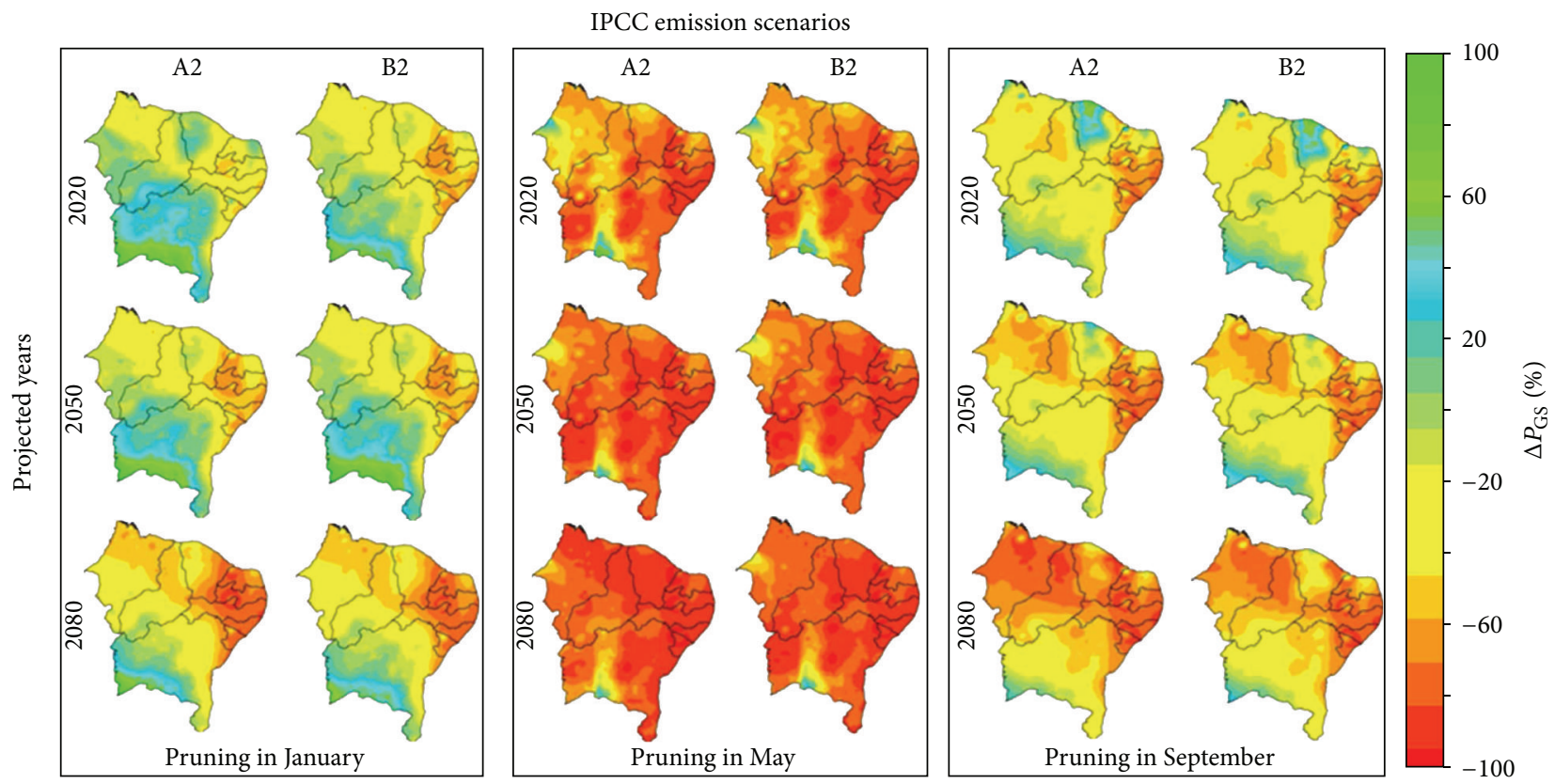

FIGURE 6: Spatial variation of the growing season precipitation differences in percentage $\left(\Delta P_{\mathrm{GS}}\right)$, between the baseline (1961-1990) and the projected years of 2020,2050, and 2080, considering three different pruning dates along the year, an average growing season of four months for the cv. Syrah, and the IPCC A2 and B2 emission scenarios in the Brazilian Northeastern region.

a wine unbalance with instability for the phenolic and aromatic composition [8-10]. In addition, secondary effects related to declines in soil structure and increases of soil salinity could occur $[15,16]$, favouring high concentrations of $\mathrm{Na}, \mathrm{K}$, and $\mathrm{Cl}$ in the tropical wines [17].

Normally, the highest vineyard water requirements occur when the pruning dates are centred in September and the lowest when they are around March. Among the Brazilian Northeastern states, Piauí (PI), Ceará (CE), and Rio Grande do Norte (RN) are highlighted, showing the largest evapotranspiration rates, which may correspond to good yield if water is available. However, some care must be taken in case of water scarcity, having ample room for wine grape water productivity improvements in situations of lower atmospheric demands [24].

Comparing the long-term regional daily averaged vineyard water requirements of 2.5 to $3.3 \mathrm{~mm} \mathrm{day}^{-1}$ from the current study with water use from five experiments under different conditions [38-42], the results from the upscaling techniques used in the current study seem to be plausible. However, as the growing seasons in tropical climates are shorter, the total evapotranspiration rates are lower than those from temperate conditions.

After computing the ongoing and outgoing components of the climatic water balance, it was observed that the lowest natural vineyard moisture conditions occur for pruning dates from May to August. These conditions will avoid plant diseases, root respiration problems, and direct damage to the berries promoted by excess of precipitation, favouring better quality of both must and wine [19]. The highest baseline moisture levels for pruning done from January to April should promote the worst wine commercial production. Excessive rainfalls reduce the ripening capacity of grapes, and the impossibility of water stress application is unfavourable for the organoleptic wine quality [7]. However, the effects of moisture excess are minimized along the IPCC projected years.

Considering the long-term weather data of 1961-1990, the pruning periods with the best thermohydrological conditions for wine grape crop (class C1) are from May to June. Highlights are for Bahia (BA), Pernambuco (PE), Paraíba (PB), Alagoas (AL), Sergipe (SE), and the west side of Maranhão (MA) with the largest areas inside this class. The worst thermohydrological class (C4) only occurs in the Northwestern part of Maranhão (MA) state, when the pruning is between January and March. In this last class, the highest levels of natural humidity compromise the grape sanity and the enological potential [19]. It is important to note that, even if $\mathrm{C} 3$ and $\mathrm{C} 4$ areas not being suitable during the wettest period of the year in the Brazilian Northeast, they will present favourable conditions ( $\mathrm{Cl}$ class) when the pruning dates are from June to October.

Taking into account the projected years, there are general air temperature increases during the growing seasons with increments of $\mathrm{C} 2$ and decreases in $\mathrm{Cl}$ areas, which may contribute to more problems for elaborating the Brazilian tropical wines, because of increments of alcohol content and decreases of acidity, increasing $\mathrm{pH}[9,10]$.

The most important effect from climate changes for wine production in the Brazilian Northeast region should be to take more care of the increasing thermal conditions regarding the wine quality. Examples of attention to this problem are the addition of tartaric acid to address the imbalance of acidity and the reverse osmosis procedures to dealcoholise wine [21]. 


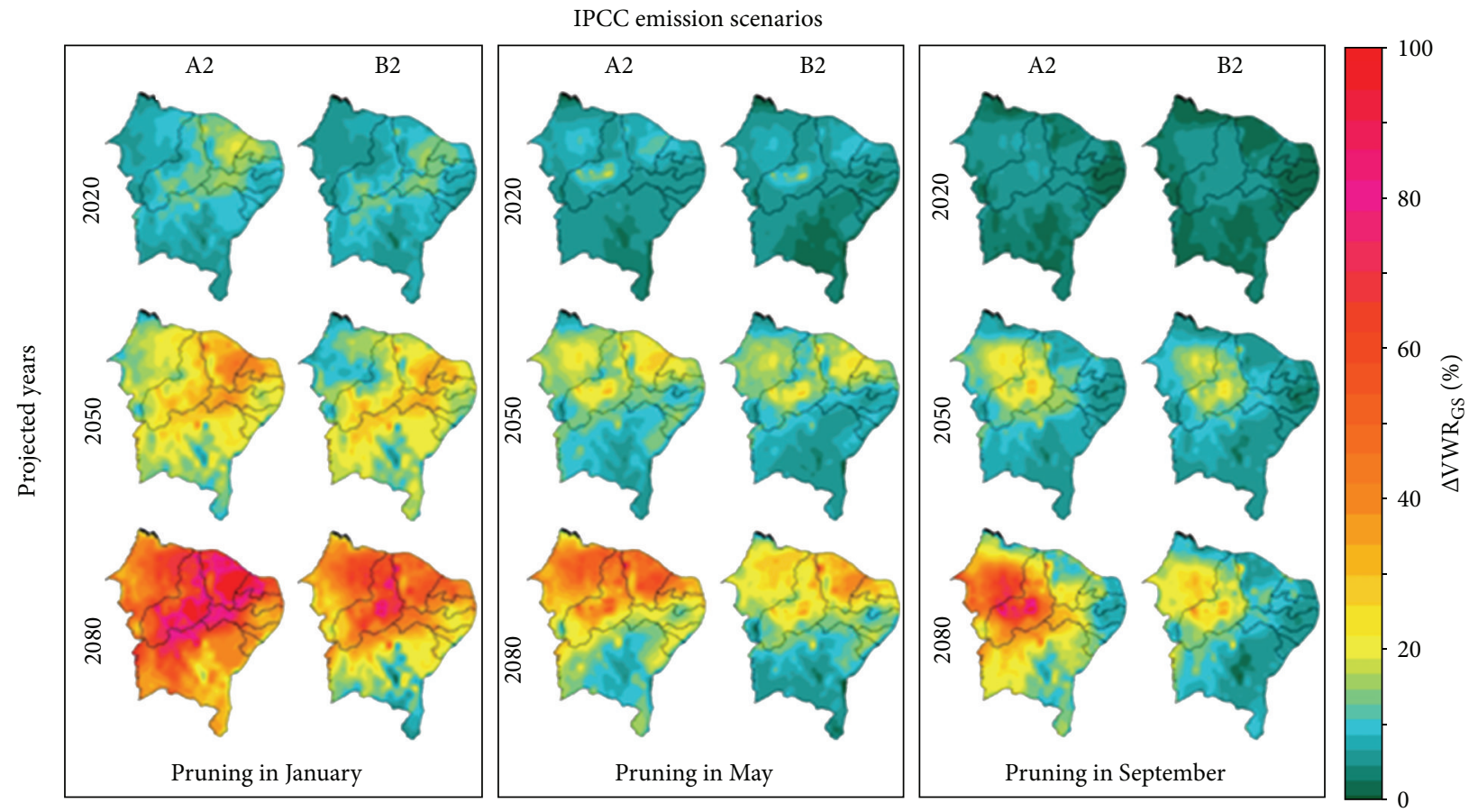

FIGURE 7: Spatial variation of the growing season vineyard water requirement differences in percentage $\left(\Delta V W R_{G S}\right)$ between the baseline (1961-1990) and the projected years of 2020, 2050, and 2080, considering three different pruning date conditions along the year, an average growing season of four months for the cv. Syrah, and the IPCC A2 and B2 emission scenarios in the Brazilian Northeastern region.
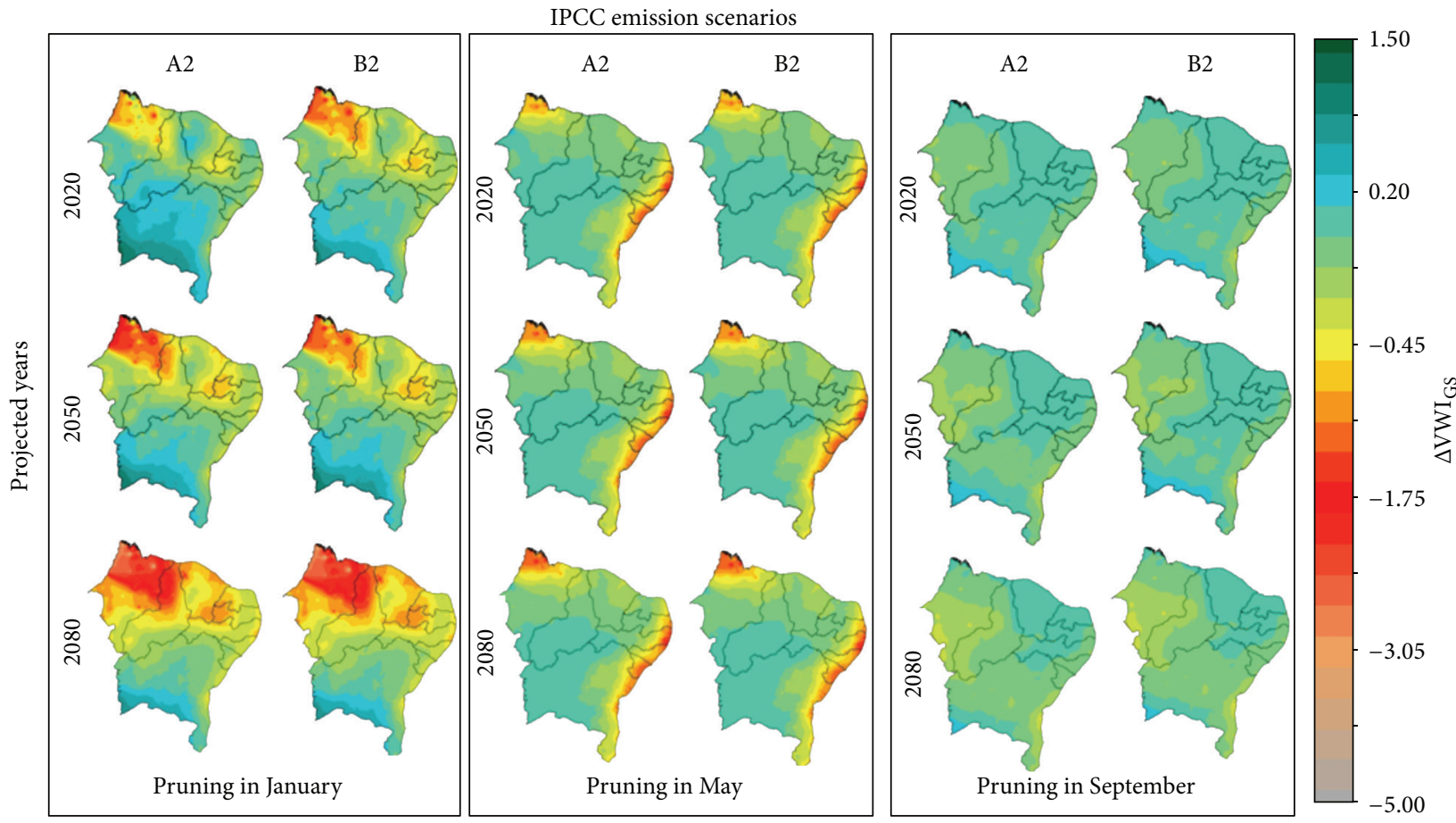

FIGURE 8: Spatial variation of the wine grape growing season vineyard water index differences $\left(\Delta \mathrm{VWI}_{\mathrm{GS}}\right)$, between the baseline (1961-1990) and the projected years of 2020,2050, and 2080, considering three different pruning date conditions along the year, an average growing season of four months for the cv. Syrah, and the IPCC A2 and B2 emission scenarios in the Brazilian Northeastern region. 


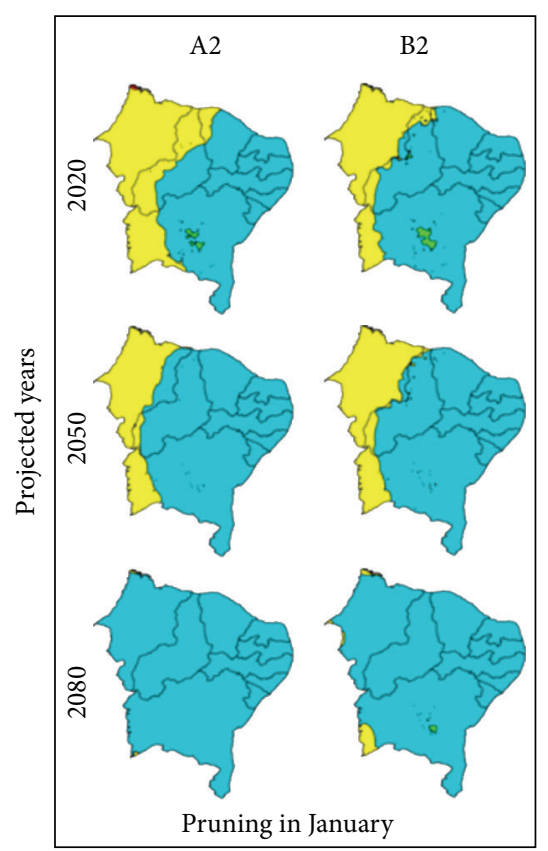

- C1: $\mathrm{VWI}_{\mathrm{GS}} \leq 2$ and $T_{\mathrm{GS}}<24^{\circ} \mathrm{C}$

- $\mathrm{C} 2: \mathrm{VWI}_{\mathrm{GS}} \leq 2$ and $T_{\mathrm{GS}} \geq 24^{\circ} \mathrm{C}$
IPCC emission scenarios
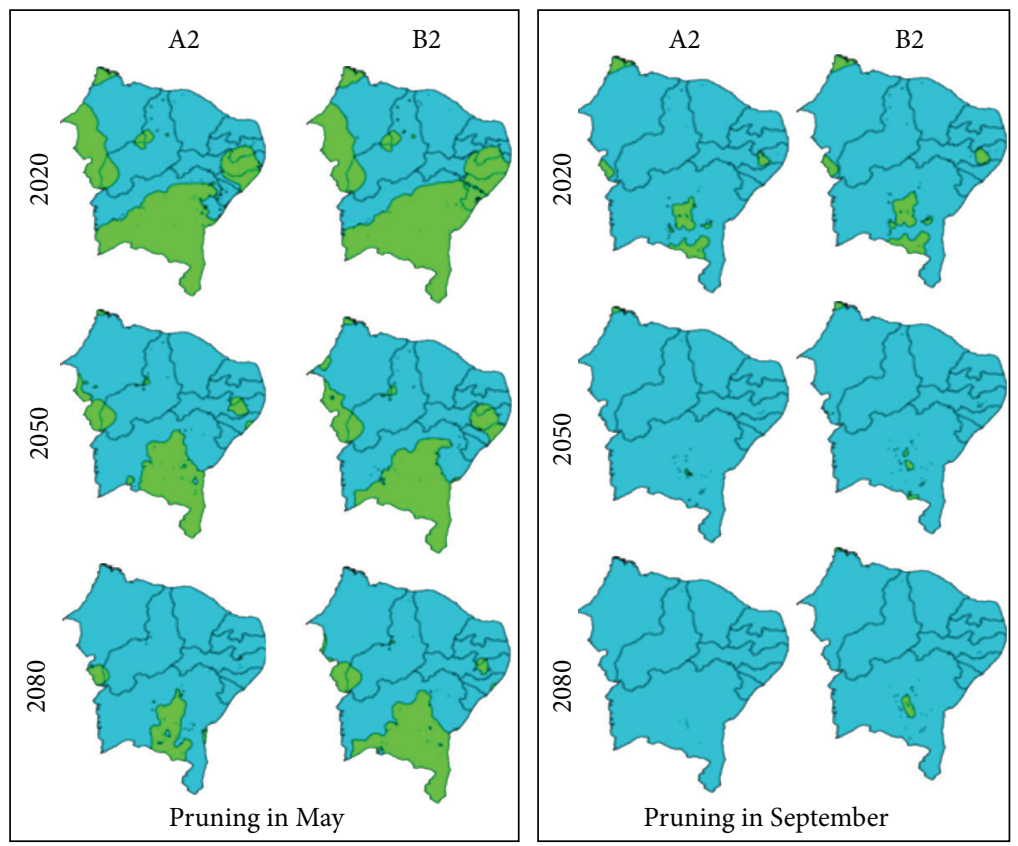

1. $3: 2<\mathrm{VWI}_{\mathrm{GS}} \leq 4$

- $\mathrm{C} 4: \mathrm{VWI}_{\mathrm{GS}}>4$

FIGURE 9: Class maps for the thermohydrological conditions of wine grape, cv. Syrah, under three different pruning dates and with an average growing season of four months considering the projected years of 2020, 2050, and 2050 for the IPCC A2 and B2 emission scenarios in the Brazilian Northeastern region.

The differentiating effects of changing precipitation patterns among areas in the current research are in agreement with Webb [23], who predicted decreasing or increasing rainfall during the growing seasons, depending upon the vineyard areas in Australia, by 2030 and 2050. On the other hand, increments in water requirements along the years agreed with Anderson et al. [21], who reported vineyard evapotranspiration rising up to $30 \%$ by 2070 in that country.

In the Brazilian Northeast, the increases of wine grape water consumption during the rainy period are important, because the subsequent months strong reductions in precipitation are also predicted, which means higher irrigation requirements during the climatologically driest periods. The simultaneous increases in atmospheric demand and decreases in rainfall amounts will call more attention for improvements of vineyard water productivity [24].

Accounting for the most suitable areas for wine grape crop in the Brazilian Northeast, their reductions are more drastic than those reported by Webb et al. [11]. According to these authors, considering a high emission scenario, decline in suitable areas by 2050 around $44 \%$ is predicted in Australia. However, the current results are similar in magnitude to those reported by White et al. [12] in USA, who concluded that, by the end of the 21st century, suitable grape production areas could reduce by $81 \%$.

It is important to keep the current analyses of the projected vineyard thermohydrological conditions with caution, as uncertainties arise inherent to the future social-economic status of the population and technological changes, as these aspects are the basis for the IPCC scenarios simulations.

To make the developed models in the Brazilian semiarid conditions applicable to other wine grape varieties and climatic areas, probably one needs to adjust the regression coefficients of the equation relating the crop coefficient and the accumulated degree days.

\section{Conclusions}

Bioclimatic indicators, based on the relations between the crop coefficient, the reference evapotranspiration, and the accumulated degree days, together with precipitation and air temperature data, allowed the large-scale classification of the thermohydrological conditions for wine grape production in the Brazilian Northeast (region), considering long-term and projected time scenarios.

The growing season values of the vineyard water requirements together with those of the total of precipitation were used for the development and application of vineyard water indicator. This indicator joined with growing season air temperature data was used to classify four different thermohydrological conditions in the Brazilian Northeaster region.

The modelling has the advantage of incorporating the thermal effects during the vineyard crop stages, extrapolating the water variables to different spatial-temporal scales. 
To make them applicable to other climatic areas, probably, the only thing needed is to adjust the regression coefficients of the equation relating the crop coefficient and the accumulated degree days.

The delimitation of the vineyard thermohydrological conditions by using the bioclimatic indices, joined with other ecological characteristics, is suitable for a rational planning of commercial wine production expansion in the Brazilian Northeast considering different pruning dates and time scenarios. This information is essential in situations of rising water competition by irrigated agriculture, natural vegetation, and nonagricultural sectors.

\section{Conflict of Interests}

The authors declare that there is no conflict of interests regarding the publication of this paper.

\section{Acknowledgments}

The research herein was supported by FACEPE and CNPq, which are acknowledged for financial support to current projects on water productivity at different spatial-temporal scales in Brazil.

\section{References}

[1] International Panel on Climate Change, "Climate change 2001: the physical scientific basis," Working Group 1, IPCC Third Assessment Report, Cambridge University Press, Cambridge, UK, 2011.

[2] International Panel on Climate Change, "Climate change 2007: the physical scientific basis. Summary for policymakers," Contribution of Working Groups I to the Forth Assessment Report of the Intergovernmental Panel on Climate Change, Cambridge University Press, Cambridge, UK, 2007.

[3] G. V. Jones, M. A. White, O. R. Cooper, and K. Storchmann, "Climate change and global wine quality," Climatic Change, vol. 73, no. 3, pp. 319-343, 2005.

[4] J. Gladstones, "Climate and Australian viticulture," in Viticulture, Volume 1: Resources, P. Dry and B. G. Coomb, Eds., pp. 90118, Winetitles, Adelaide, Australia, 2004.

[5] A. J. Winkler, J. A. Cook, W. M. Kliewer, and L. A. Lider, General Viticulture, University of California Press, Berkeley, Calif, USA, 1974.

[6] A. Costacurta and G. Roselli, "Critères climatiques et édaphiques pour l'établissement des vignobles," Le Bulletin de l'Organisation Internationale de la Vigne et du Vin, vol. 53, pp. 783-786, 1980.

[7] P. Huglin and C. Schneider, Biologie et écologie de la vigne, Lavoisier, Paris, France, 1998.

[8] C. R. Hale and M. S. Buttrose, "Effect of temperature on ontogeny of berries of Vitis vinifera L. cv. Cabernet Sauvignon," Journal of the American Society for Horticultural Science, vol. 99, pp. 390-394, 1974.

[9] J. M. Tarara, J. Lee, S. E. Spayd, and C. F. Scagel, "Berry temperature and solar radiation alter acylation, proportion, and concentration of anthocyanin in Merlot grapes," American Journal of Enology and Viticulture, vol. 59, no. 3, pp. 235-247, 2008.
[10] R. M. de Orduña, "Climate change associated effects on grape and wine quality and production," Food Research International, vol. 43, no. 7, pp. 1844-1845, 2010.

[11] L. B. Webb, P. H. Whetton, and E. W. R. Barlow, "Climate change impacts on Australian viticulture," in Proceedings of the 13th Australian Wine Industry Technical Conference (AWITC '08), R. Blair, P. Williams, and P. Sakkie, Eds., pp. 99-105, Australian Wine Industry Technical Conference, Urrbrae, Australia, 2008.

[12] M. A. White, N. S. Diffenbaugh, G. V. Jones, J. S. Pal, and F. Giorgi, "Extreme heat reduces and shifts United States premium wine production in the 21st century," Proceedings of the National Academy of Sciences of the United States of America, vol. 103, no. 30, pp. 11217-11222, 2006.

[13] B. Ganichot, "Evolution de la date des vendanges dans les Côtes du Rhône méridionales," in Actes des 6émes rencontres rhodaniennes, pp. 38-41, Institut Rhodanien, Orange, France, 2002.

[14] C. V. Jones, "Climate change: observations, projections, and general implications for viticulture and wine production," in Economics Department Working Paper No. 7, E. Essick, P. Griffin, B. Keefer, S. Miller, and K. Storckmann, Eds., pp. 1-7, Whitman College, Washington, DC, United States, 2007.

[15] L. R. Clark, R. W. Fitzpatrick, R. S. Murray, and M. G. McCarthy, "Vineyard soil degradation following irrigation with saline groundwater for twenty years," in Proceedings of the 17th World Congress of Soil Science, no. 33, pp. 1115 CD ROM, International Union of Soil Science, Bangkok, Thailand, 2002.

[16] A. L. Richards, J. L. Hutson, and M. G. McCarthy, "Monitoring and modeling transient rootzone salinity in drip irrigated viticulture," in Proceedings of the 13th Australian Wine Industry Technical Conference (AWITC '08), R. Blair, P. Williams, and P. Sakkie, Eds., pp. 212-217, Australian Wine Industry Technical Conference, Urbrae, Australia, 2008.

[17] R. R. Walker, D. H. Blackmore, P. R. Clingeleffer et al., "Salinity effects on vines and wines," Le Bulletin de l'Organisation Internationale de la Vigne et du Vin, vol. 76, pp. 200-227, 2003.

[18] M. Keller, "Managing grapevines to optimise fruit development in a challenging environment: a climate change primer for viticulturists," Australian Journal of Grape and Wine Research, vol. 16, no. 1, pp. 56-69, 2010.

[19] A. H. C. Teixeira, Water Productivity Assessments from Field to Large Scale: A Case Study in the Brazilian Semi-Arid Region, LAP Lambert Academic Publishing, Saarbrücken, Germany, 2009.

[20] L. B. Webb, P. H. Whetton, and E. W. R. Barlow, "Modelled impact of future climate change on the phenology of winegrapes in Australia," Australian Journal of Grape and Wine Research, vol. 13, no. 3, pp. 165-175, 2007.

[21] K. Anderson, C. Findlay, S. Fuentes, and S. Tyerman, Garmaute Climate Change Review: Viticulture, Wine and Climate Change, University of Adelaide, Adelaide, Australia, 2008.

[22] D. I. Jackson and N. J. Cherry, "Prediction of a district's graperipening capacity, using a latitude-temperature index (LTI)," American Journal of Enology and Viticulture, vol. 1, pp. 19-28, 1988.

[23] L. B. Webb, The impact of projected greenhouse gas-induced climate change on the Australian wine industry [Ph.D. thesis], School of Agriculture and Food Systems, University of Melbourne, Victoria, Australia, 2006

[24] A. H. C. Teixeira and L. H. Bassoi, "Crop water productivity in semi-arid regions: from field to large scales," Annals of Arid Zone, vol. 48, pp. 1-13, 2009. 
[25] N. Nakicenovic, J. Alcamo, G. Davis et al., IPCC Special Report on Emissions Scenarios, Cambridge University Press, Cambridge, UK, 2000.

[26] V. Bonnardot, O. Planchon, V. A. Carey, and S. Cautenet, "Diurnal wind, relative humidity and temperature variation in the Stellenbosch-Groot Drakenstein wine producing area," South African Journal for Enology and Viticulture, vol. 23, pp. 62-71, 2002.

[27] J. Tonietto and A. Carbonneau, "A multicriteria climatic classification system for grape-growing regions worldwide," Agricultural and Forest Meteorology, vol. 124, no. 1-2, pp. 81-97, 2004.

[28] S. Hormazábal, G. Lyon, and A. Carbonneau, "Variabilité et limite du macroclimat viticole méditerranéen des Départements de l'Aude, de l'Hérault et du Gard, dans le Midi de la France," Progrès Agricole et Viticole, vol. 119, pp. 102-110, 2002.

[29] D. Blanco-Ward, J. M. García Queijeiro, and G. V. Jones, "Spatial climate variability and viticulture in the Miño River Valley of Spain," Vitis, vol. 46, no. 2, pp. 63-70, 2007.

[30] M. Ferrer, R. Pedocchi, M. Michelazzo, G. Gonzalez-Neves, and A. Carbonneau, "Delimitación y descripción de regiones vitícolas del Uruguay en base al método de clasificación climática multicriterio utilizando índices bioclimáticos adaptados a las condiciones del cultivo," Agrociencia, vol. 11, pp. 47-56, 2007.

[31] C. Montes, J. F. Perez-Quezada, A. Peña-Neira, and J. Tonietto, "Climatic potential for viticulture in Central Chile," Australian Journal of Grape and Wine Research, vol. 18, no. 1, pp. 20-28, 2012.

[32] E. P. Cavalcanti and V. P. R. Silva, "Programa computacional para a estimativa da temperatura do ar para a região Nordeste do Brasil," Revista Brasileira de Engenharia Agrícola e Ambiental, vol. 10, pp. 140-147, 2006.

[33] C. W. Thornthwate, "An approach toward a rational classification of climate," Geographical Review, vol. 38, pp. 55-94, 1948.

[34] R. G. Allen, L. S. Pereira, D. Raes, and M. Smith, “Crop evapotranspiration: guidelines for computing crop water requirements," FAO Irrigation and Drainage Paper 56, FAO, Rome, Italy, 1998.

[35] A. H. D. C. Teixeira, W. G. M. Bastiaanssen, and L. H. Bassoi, "Crop water parameters of irrigated wine and table grapes to support water productivity analysis in the São Francisco river basin, Brazil," Agricultural Water Management, vol. 94, pp. 3142, 2007.

[36] International Panel on Climate Change, "IPCC SRES climate scenarios (the IPCC Data Distribution Centre)," 2006, http:// www.ipcc-data.org/sres/gcm_data.html.

[37] J. A. Marengo, I. F. A. Calvalcanti, P. Satyamurty et al., "Assessment of regional seasonal rainfall predictability using the CPTEC/COLA atmospheric GCM," Climate Dynamics, vol. 21, no. 5-6, pp. 459-475, 2003.

[38] L. E. Williams, C. J. Phene, D. W. Grimes, and T. J. Trout, "Water use of mature Thompson Seedless grapevines in California," Irrigation Science, vol. 22, no. 1, pp. 11-18, 2003.

[39] I. A. M. Yunusa, R. R. Walker, and P. Lu, "Evapotranspiration components from energy balance, sapflow and microlysimetry techniques for an irrigated vineyard in inland Australia," Agricultural and Forest Meteorology, vol. 127, no. 1-2, pp. 93-107, 2004.

[40] G. Rana, N. Katerji, M. Introna, and A. Hammami, "Microclimate and plant water relationship of the "overhead" table grape vineyard managed with three different covering techniques," Scientia Horticulturae, vol. 102, no. 1, pp. 105-120, 2004.
[41] L. E. Williams and J. E. Ayars, "Grapevine water use and the crop coefficient are linear functions of the shaded area measured beneath the canopy," Agricultural and Forest Meteorology, vol. 132, no. 3-4, pp. 201-211, 2005.

[42] S. Ortega-Farias, M. Carrasco, A. Olioso, C. Acevedo, and C. Poblete, "Latent heat flux over Cabernet Sauvignon vineyard using the Shuttleworth and Wallace model," Irrigation Science, vol. 25, no. 2, pp. 161-170, 2007. 


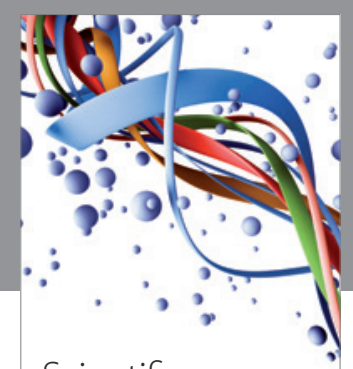

Scientifica
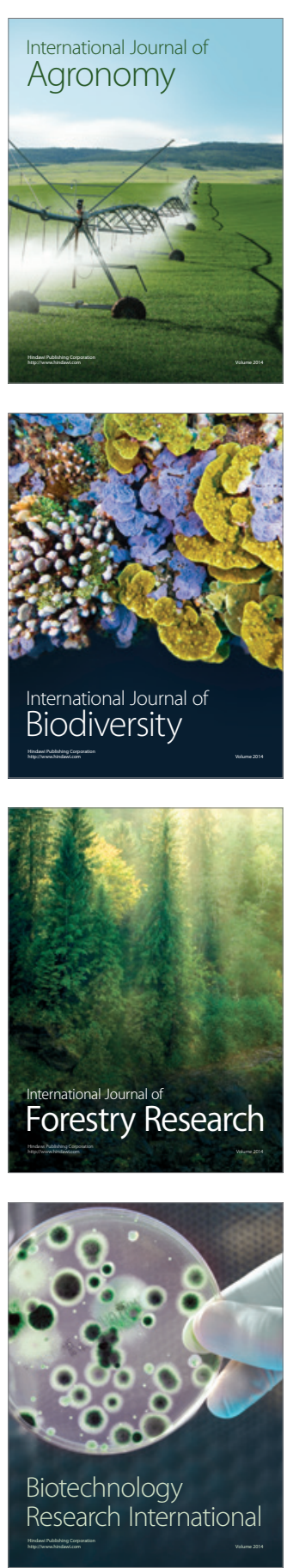
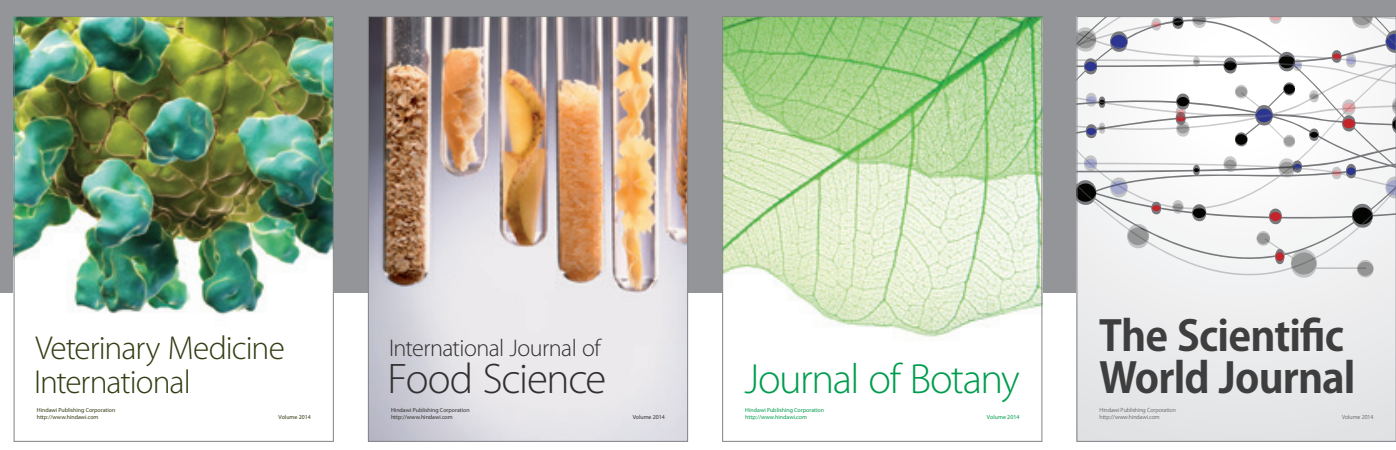

The Scientific World Journal
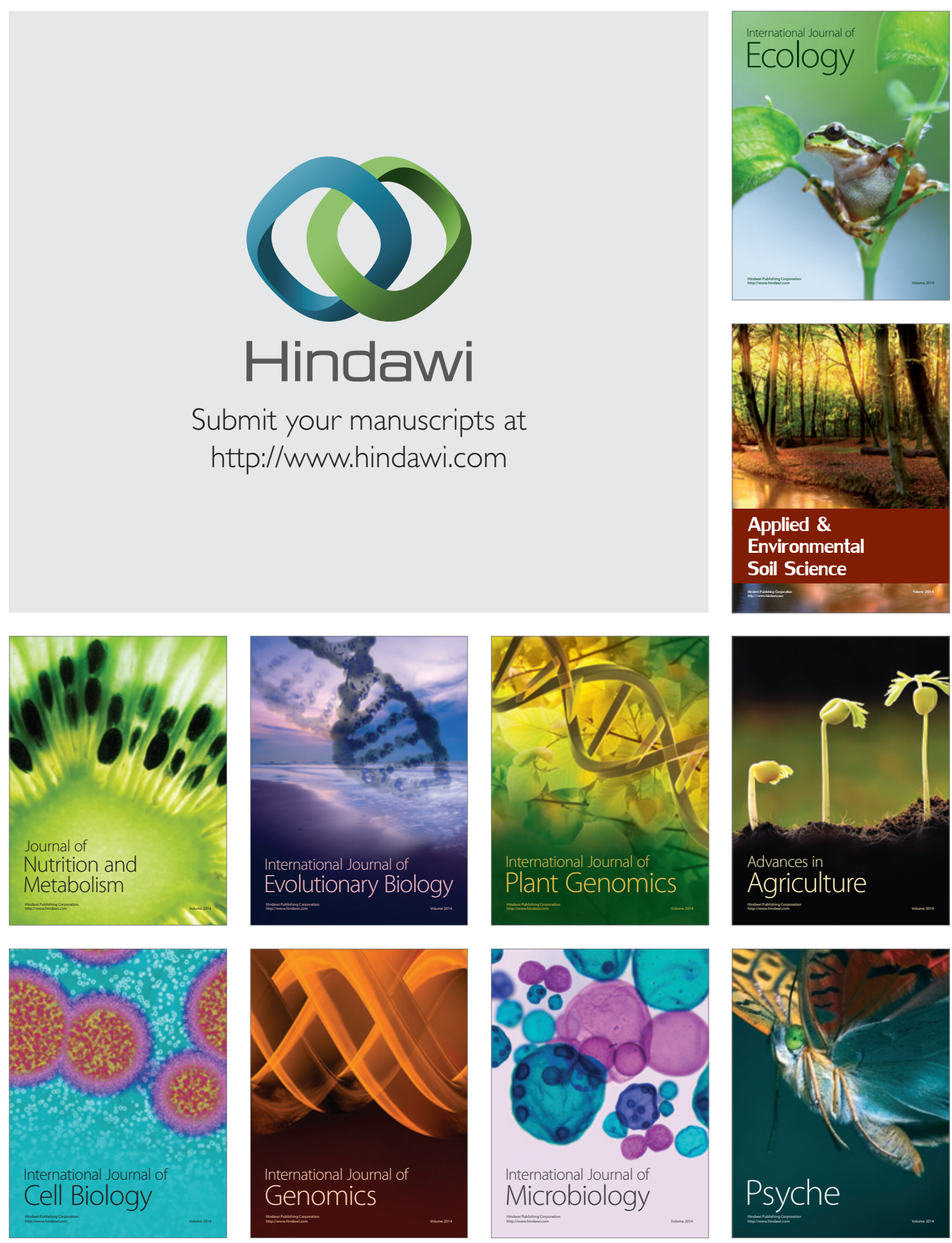